\title{
Integration of Project Management with NPD Process
}

\author{
A Metalworking Company Case Study
}

\author{
Irene Costa, Gabriela Fernandes, Anabela Tereso \\ Production and Systems Department / ALGORITMI Research Centre \\ University of Minho, Campus de Azurém \\ 4804-533 Guimarães, Portugal \\ irenecdacosta@gmail.com,g.fernandes@dps.uminho.pt, anabelat@dps.uminho.pt
}

\begin{abstract}
While the literature provides some reflection on the relation between Project Management and New Product Development (NPD), there are still doubts on how these practices can be integrated. This study made a contribution on how a metalworking company should integrate Project Management with their established NPD process. Additionally, a proposal about how the company should integrate the Subproject with the Global Project is made. Two main concerns guided the development of this work: the integrated project management process should be useful and easy to use. Therefore, only six main project management practices are proposed: project charter, initial project plan, progress reports, updated plan, open point list and lessons learned.
\end{abstract}

Keywords-project management; new product development; subproject; global project; metalworking company

\section{INTRODUCTION}

There is an increasing business competition, being the demand for reduced costs, increased quality and reduced leadtime, the main focuses of the industry [1]. The development of new products presents a solution for companies to remain competitive [2] and provides them with future business opportunities [3]. However, developing a new product on time and within budget is a huge challenge, so project management is an area that must be considered during this process [4].

The New Product Development (NPD) process integrates the industry best practices with proven business practices [4], so functional areas, such as Engineering, Marketing and Procurement, must collaborate continuously to achieve the objectives of the project [4-6]. The NPD process is complex and highly risky, so enterprises have to be on alert, as high failure rate and low efficiency go commonly together with this kind of processes [2]. Classic approaches emphasize the importance of integration in NPD. Pugh [7] developed a NPD approach called Total Design, which considered that designers and engineers should be more involved in the entire project to match the market/user needs. Cross-functional integration is a process that combines the various functional business activities within an organization and is crucial to new product success [8-12].
NPD projects have been gaining attention from companies. According to Drennan [13], the greater domestic and global competition, continuous development of new technologies, constantly changing customer needs, shorter product life cycles, and rising costs, place organizations under constant pressure to meet time, budget, and performance requirements, and are therefore, reasons for developing new products.

The high uncertainty in NPD projects leads to decreased effectiveness of project management $[14,15]$. It is difficult to detail project tasks, task sequence, task interdependencies and task times before project execution starts [16]. Lewis, Welsh, Dehler and Green [17] have shown that the intensity of project management in NPD is higher during the development phase than during the conceptual phase [3]. Typically, this type of projects has informal project management, with lack of record and documentation of the activities [4]. To study the best way to apply project management in NPD projects remains a relevant research topic [3].

This paper focuses on a particular type of project and on a particular company. It is characterized by being a national medium-sized company, belonging to the metallurgical sector. Medium-sized companies are defined as companies that employ fewer than 250 persons and either have an annual turnover that does not exceed EUR 50 million, or an annual balance sheet not exceeding EUR 43 million [18]. National companies are companies that maintain assets and/or operations primarily in one country. In the research methodology section the company is presented in detail. The main objective of the projects under study is the development of new tools. The development of new tools are in fact subprojects of what we call global projects development of new metal part projects. The development of these projects is also explained in detail in the projects characterization section.

This research aimed to integrate the project management and the NPD process by developing an integrated project management process. There are many published paper that discuss NPD and project management, however, very little research shows how to integrate project management with NPD 
process $[3,4]$. Because the research focused the context of subprojects, it also aimed to understand how to integrate the subproject with the global project. Therefore, the research was conducted by two research questions: 1 . How to integrate the project management process with the NPD process? 2. How to integrate the subproject with the global project?

The paper follows a common structure. After the introduction, the second section makes a brief literature review on project management in general and in NPD. The third section describes the research methodology. Then the fourth section presents the characterization of the projects carried out in the company. The fifth section presents the results and discussion of the development of an integrated project management process for the subproject, and the integration of the subproject with the global project. Finally, the main conclusions and future work are discussed.

\section{LITERATURE REVIEW}

\section{A. Project Management}

Project management is an area of knowledge that exists since the antiquity. Projects such as the Pyramids of Giza and the Great Wall of China are examples of its application. However, it was only in the second half of the twentieth century that the application of project management tools and techniques in the business context began. World War II was a lever for the growth of project management, due to the Manhattan and Apollo projects. The Manhattan project aimed to develop the atomic bomb and the Apollo project intended to put the Man on the Moon. Both projects were successful, achieved their intended goals and had a major impact around the world. Technological advances and the emergence of the internet have increased efficiency in the management and control of projects [19].

Project is defined by PMBoK [20], from the Project Management Institute (PMI), as "a temporary endeavor undertaken to create a unique product, service, or result". There are several existing definitions of project [21-23], yet all have similarities - a project is characterized by its rarity, the restrictions, the multidisciplinarity and the complexity.

Projects should be completed on established time, follow forecast budget and achieve established quality requirements [24]. According to PMI's 2016 Pulse of the Profession, 62\% of projects meet original goals/business intent, $53 \%$ are completed within original budget and $49 \%$ are completed on time [25]. However, there are other factors to consider in order to achieve project success, since projects are carried out with the aim of improving results and performance of organizations [26].

With the acceleration of knowledge reproduction, increase of goods and services demand, and increasing market competition, the necessity of project management became increasingly evident [27]. PMI [20] defines project management as "the application of knowledge, skills, tools, and techniques to project activities to meet the project requirements".

In 2016, projects that use proven project management practices were 2,5 times more successful [25]. According to
Abbasi and Al-Mharmah [28], companies adopt project management to face performance problems, to organize and accomplish deadlines, existing a tendency toward project management growth and acceptance when resources become scarce. Pinto and Kharbanda [29] also added a rapid product development, the efficient use of human and financial resources and increased communication as the main expected benefits.

Often, companies use project management methodologies as a management tool, so that changes are implemented [30]. A study of thirty metalworking companies [31] revealed that $51 \%$ of the surveyed companies develop their own management methodology and $27 \%$ of the cases used a formal reference framework. However, in $19 \%$ of the cases a formal methodology of project management was not applied and only $3 \%$ used the IPMA (International Project Management Association) competence baseline as a framework of reference [31].

\section{B. Project Management in NPD}

The utilization of traditional project management methods in product development may not be enough to get high product development performance and market success [32]. Gerwin and Barrowman [33] advocate a managerial approach called Integrated Product Development, as one of the most significant contemporary trends in NPD management. This approach aims to improve product development performance through managing the overlapping, parallel execution and concurrent workflow of activities.

The first approach that included project management in the product development process was developed in 1986 by Takeuchi and Nonaka [34]. They considered that for companies to remain competitive, the sequential traditional product development method is not enough. According to the authors, a set of characteristics must be incorporated to improve internal collaboration. These characteristics are: built-in instability, self-organizing project teams, overlapping development phases, multi-learning, subtle control, and organizational transfer of learning [34]. This approach is supported by several researches on Integrated Product Development [35-42].

The adoption of project management standards can improve the product development efficiency [43]. Pons [3] concluded that there are significant gaps in the PMBoK for NPD, since project management does not fully meet the needs of NPD. Even though, he suggests that NPD practitioners should use project management and the $\mathrm{PMBoK}$. These projects are not easily managed with any methodology, and project management may be better than none.

The need to innovate leads organizations to create NPD programs [44] and NPD portfolios [45] to ensure delivery of successful new products. Product scope management is the basis of NPD projects, so changes assume a high importance [45]. NPD is characterized by uncertainties and ambiguities that can compromise the project execution. To fulfill the NPD project principle of meeting customer needs, changes in scope during the project are commonly imposed, which can lead to delays in product delivery [44]. 


\section{RESEARCH METHODOLOGY}

The research methodology adopted in this paper was a case study, developed in a metalworking company, more specifically, ETMA Metal Parts. The case study methodology is used to research a specified phenomenon in a real context, using multiple sources of evidence [46].

\section{A. Case Study Background}

ETMA Metal Parts is located in Braga, Portugal, and was founded in 1940. ETMA manufactures metal parts, and, throughout the years, it has expanded its activity to different sectors, such as automotive, electrical, home appliances, plastics fixation and injection. Nowadays, ETMA produces a large portfolio of products, presenting itself on the market with 10 integrated production processes, which makes the company a unique case in Europe. In 2016, ETMA achieved a turnover of around 8.885 million euros and manufactured more than 300 million parts.

The company also manufactures tools that allow the production of metal parts. The built tools are mostly intended for the stamping sector; however, whenever necessary, simple tools are built for the screw and wire sectors. Stamping tools are characterized by being progressive tools, used in eccentric presses and fast presses, and tools of formation (Bihler).

ETMA develops several subprojects that require project management, although its utilization is ineffective and inefficient. Lack of a structure that would define how to adopt project management practices and difficulties in completing projects on time are the main problems in the development of subprojects. To solve these problems, the company wants to improve project management practice.

\section{B. Reseach Methods}

The collection and analysis of the data, performed between September 2016 and March 2017, was based on participant observation and organizational documentation analysis. Observation is characterized by being participative, since the researcher is inserted in the group and participates in the activities observed [46]. Techniques such as discussion and informal conversations were used, having as main participants the elements of the Department of Project Management and the Department of New Tools/Project. The organizational documentation analysis supported the observations made.

For the adoption of these research methods, the researcher was inserted and integrated into the company. The collaboration of projects' stakeholders was fundamental to conduct this research. Their cooperation was not always easy due to the lack of time, but due to the importance of the research to the company, the stockholders involved manage to collaborate, as needed.

\section{PROJECTS CHARACTERIZATION}

This paper focuses on the new tools development projects, which are subprojects of the metal parts development projects.
TABLE I. Typologies of THE Global PROJECTS

\begin{tabular}{|l|l|l|}
\hline \multicolumn{2}{|c|}{ Types of projects } & \multicolumn{1}{c|}{ Description } \\
\hline P & $\begin{array}{l}\text { Prototypes supply } \\
\text { projects }\end{array}$ & $\begin{array}{l}\text { These projects provide small quantities of } \\
\text { parts, which are produced manually using } \\
\text { laser equipment as a resource. This project } \\
\text { typology is used when customers need parts } \\
\text { quickly. }\end{array}$ \\
\hline IS & $\begin{array}{l}\text { Initial Samples } \\
\text { supply projects }\end{array}$ & $\begin{array}{l}\text { The main goal of this type of projects is the } \\
\text { development of a part that can be produced } \\
\text { in series. For that purpose, a tool is built to } \\
\text { obtain the desired part. This tool produces } \\
\text { initial samples that must be approved by the } \\
\text { customer for serial production to start. }\end{array}$ \\
\hline PIS & $\begin{array}{l}\text { Prototypes and } \\
\text { Initial Samples } \\
\text { supply projects }\end{array}$ & $\begin{array}{l}\text { Integration of the development of } \\
\text { prototypes and initial samples. }\end{array}$ \\
\hline
\end{tabular}

\section{A. Global Project}

ETMA Metal Parts' main activity is metal parts production, so it develops several development of metal parts projects. Table I highlights the typologies of projects in metal part development (the global projects). There are three types of global projects: $\mathrm{P}$ (Prototypes), IS (Initial Samples) and PIS (Prototypes and Initial Samples). The development of new tools is related to IS and PIS types of global projects.

These types of projects involve several people, thus making it necessary to ensure that all projects' stakeholders are identified, so the projects can be successful. Table II identifies all stakeholders and the role each one plays in the project. Due to the company's functional structure, stakeholders are identified by departments.

The Project Management department is responsible for managing the global projects' activities, using the SharePoint platform as support. Project management documents have typically a digital format, that is, they can be consulted in SharePoint, not having a physical support.

The global project is divided into seven phases:

- Preparation of Prototypes: to ensure the initial planning of the prototyping activities and the

TABLE II. STAKEHOLDERS REGISTER

\begin{tabular}{|l|l|}
\hline \multicolumn{1}{|c|}{ Stakeholder } & \multicolumn{1}{c|}{ Function } \\
\hline Administration Board & $\begin{array}{l}\text { Responsible for authorizing and supporting } \\
\text { projects within the organization. }\end{array}$ \\
\hline Customer & Organization that buys the final product. \\
\hline Project Management & $\begin{array}{l}\text { Responsible for managing all the necessary } \\
\text { activities for the development of parts. }\end{array}$ \\
\hline New Tools/Project & $\begin{array}{l}\text { Responsible for coordinating and executing all } \\
\text { necessary activities for tools construction. }\end{array}$ \\
\hline Production & $\begin{array}{l}\text { Responsible for coordinating all serial } \\
\text { production activities. }\end{array}$ \\
\hline Planning & $\begin{array}{l}\text { Responsible for scheduling tool tests on } \\
\text { equipment. }\end{array}$ \\
\hline Technical Office & $\begin{array}{l}\text { Responsible for coordinating the preparation of } \\
\text { technical documents for the parts production, as } \\
\text { defined with the customer, ensuring the control } \\
\text { and register of technical standards and the } \\
\text { customer's special requirements. }\end{array}$ \\
\hline Quality & $\begin{array}{l}\text { Responsible for checking the dimensions of the } \\
\text { parts produced, considering the requirements of } \\
\text { the customer. }\end{array}$ \\
\hline Suppliers & $\begin{array}{l}\text { Responsible for providing materials and services } \\
\text { for the project development. }\end{array}$ \\
\hline
\end{tabular}


commitment of the stakeholders involved in the global project development;

- Execution of Prototypes: to execute the prototyping activities and to deliver the prototypes;

- Preparation of Initial Samples: to guarantee the planning of the initial samples' activities and the alignment of the global project objectives with the stakeholders

- Studies of Initial Samples: to establish and specify the means to develop the initial samples;

- Development of Definitive Means: to create the means for producing the initial samples;

- Execution of Initial Samples: to test the means, to produce and to deliver the initial samples;

- Monitoring: to obtain formal approval of the customer, to communicate the global project closing, to archive global project documentation and to monitor the production activities.

The presented phases are related to the PIS type of global projects. The $\mathrm{P}$ type of global projects comprises the two first phases and the last phase, and the IS type of global projects involves the remaining five phases.

\section{B. Subproject}

Subprojects have the objective of developing a new tool that allows the posterior mass production of a metal part. The need to create the tool arises from the customer's need to obtain a metal part. The development of the tool is a means for the development of the metal part.

As for the development of new tools, the projects are not organizes in typologies, since all the processes are similar. However, there are small differences in the processes that must be followed, depending on the tool in consideration. The subproject's stakeholders are the same of the global project.

The New Tools/Project department is responsible for developing new tools. Its elements must manage the new tools project activities and ensure that these are approved in a timely manner to be used in the production of metal parts.

The development of new tools demands a very high strategic alignment, since they are a means to the development of metal parts, the main activity of the company. ETMA has many years of experience in tools development, which has granted familiarity with the scope of the majority of the subprojects. However, the scope of the product is not always known, since the complexity and the degree of innovation is high.

These subprojects present an average duration of 11 weeks; however, depending on the complexity degree and resources availability, duration may be longer. The duration refers only to product development, since project management is not considered in total project duration. Most tool projects do not meet the established deadlines.

With regard to quality, its control is carried out in the test phase to verify if the metal part specifications meet the customer's requirements, which are established in the design or prototype phase of the proposed metal part. The risks are generally associated with suppliers' failure to meet deadlines and the unavailability of resources, with a medium impact on tool projects.

The human resources of the subprojects in the company reveal a permanent effort overload, since the subproject team members are often confronted with a weekly schedule of up to 50 hours, covering 6 days a week. The subproject team comprises 3 designers, 1 milling machine operator, $2 \mathrm{CNC}$ technicians, 1 turning machine operator, 1 rectifier, 1 erosion technician and 3 fitters. Subprojects are performed internally; however, in all of them, the heat treatment is subcontracted. When there is a high volume of work, the company resorts to subcontracting of the machining and the erosion processes. There are six suppliers, one of which provides the required material and accessories, three provide machined components, another provides hardened components and the remainder provides eroded components

Regarding the product, the tools studied are characterized by being progressive tools for stamping. The progressive tools have as components: shims, lower plate, matrix, ruler, guide, saw plates, door punches, plate shock, top plate and punches. Depending on the complexity of the tool, it may have additional components, such as: additional plates, springs, lateral or lower punches, punch attachment systems, among others. The equipment used in the progressive tools are eccentric and fast Bruderer presses and Bihler automatic forming machines.

\section{RESULTS AND DISCUSSION}

\section{A. Development of an Integrated Project Management Process for the Subproject}

The development of the integrated project management process had the main theoretical foundation in the PMBoK, the most internationally known reference guide of knowledge in project management [47]. The utilization of recognized reference guides has several benefits for the company, such as: ensuring that the organization is using recognized project management practices; satisfaction of customers' requirements in the use of a recognized methodology; assistance with external recruitment; and availability of the methodology to provide training and support [48]

Project Management can contribute to a better definition of the work, as well as a better understanding of the phases to be performed to ensure deadline compliance. The integrated project management process will be used as support for the development of future projects, provided they follow a similar structure. However, this must be adapted considering the type of tool, the processes that must be followed and the various problems that may occur during its development.

This process is divided into two phases: Project Management and Product Development. Processes related to Product Development already existed informally in the company. This integrated process details the phases of Design and Tests. Regarding the Project Management processes, only the processes of the Initiation and Initial Planning phases existed prior to the authors intervention. However, the outputs of these processes have been improved to record more information. 
Therefore, the processes of the Project Follow-up and Project Closure phases were added.

\section{1) Develop Product Development Life Cycle}

Product Development begins with the development of the tool design. The next step is the most time consuming and corresponds to the tool manufacture. Upon completion, the tests are performed to obtain the samples that will be approved by the costumer. Table III shows the processes and outputs of each phase.

\section{- Design}

Design corresponds to the set of activities necessary for the tool definition, it is the activity of product design and specification. This phase uses the customer's requirements to specify the characteristics of the tool, aiming at satisfying the customer's needs.

At this phase, rigor and detail are crucial as they determine the exact measurements of the structure and its components. The existence of any failure in the design phase will compromise the operation of the following phases.

This phase includes the following processes:

- Define Strip: consists of the study of the part design and the definition of the operations that the tool will have to perform to obtain the part.

- Define Structure: corresponds to the definition of the components that the tool will have to contain to perform each of the operations.

- Design Components: consists in the realization of the individual design of each component; each design must contain the design number, the name of the component, the quantity, the material and the production processes to be used, and the identification of who designed and verified it, as well as the date of realization.

- Order the Material: involves defining the necessary material, the quantity to be acquired and the desired dimensions, as well as approaching suppliers to obtain proposals for price, delivery time and quality.

TABle III. Product DeVElopment LifE CyClE

\begin{tabular}{|l|l|l|}
\hline \multicolumn{1}{|c|}{ Phase } & \multicolumn{1}{|c|}{ Processes } & \multicolumn{1}{c|}{ Outputs } \\
\hline \multirow{4}{*}{ Design } & Define Strip & Strip Design \\
\cline { 2 - 3 } & Define Structure & Tool Structure \\
\cline { 2 - 3 } & Design Components & Components Design \\
\cline { 2 - 3 } & Order Material & $\begin{array}{l}\text { Material List } \\
\text { Budget record }\end{array}$ \\
\hline \multirow{4}{*}{ Manufacture } & Prepare Material & Prepared Material \\
\cline { 2 - 3 } & Machine Components & Machined Components \\
\cline { 2 - 3 } & Perform Heat Treatment & Tempered Components \\
\cline { 2 - 3 } & Rectify Components & Rectified Components \\
\cline { 2 - 3 } & Perform Erosion & Eroded Components \\
\cline { 2 - 3 } & Assemble Tool & Assembled Tool \\
\hline \multirow{5}{*}{ Tests } & Essay Tool & Tested Tool \\
\cline { 2 - 3 } & Control Samples Quality & Tool Validation \\
\cline { 2 - 3 } & Adjust Tool & Adjusted Tool \\
\cline { 2 - 3 } & Produce Initial Samples & Initial Samples \\
\hline
\end{tabular}

\section{- Manufacture}

The Manufacture phase is of high importance for the development of the product, since the main output of this phase is the tool. To obtain the tool, its components may go through the following processes: Prepare Material, Machine Components, Perform Heat Treatment, Rectify Components, Perform Erosion and Assemble Tool. This is the order that each component must follow; however, there are components that skip certain processes.

The processes of this phase are characterized as follows:

- Prepare Material: consists in cutting the steel considering the measurements indicated in the designs and conditioned by the arrival of the material ordered by the company.

- Machine Components: corresponds to the transformation of the raw material into a product with shape, dimensions and finishing. The machining is obtained by means of turning, milling and drilling processes.

- Perform Heat Treatment: aims to harden steel so it can face the high temperature and pressure that the tool is subjected to during the stamping phase.

- Rectify Components: aims to correct geometric irregularities produced in previous operations, whereby reducing roughness and improving the accuracy.

- Perform Erosion: to remove material from the components due to a series of electrical discharges. Usually it is used when there are some structures that are not possible to obtain in Machining.

- Assemble Tool: consists in fitting all the components as established in the design phase.

\section{- $\quad$ Tests}

The test phase consists in the final verification of the tool in a production equipment and its validation.

This phase includes the following processes:

- Essay Tool: experimental evaluation of the product; aiming to verify if the parts produced by the tool meet the agreed specifications or not. This process consists of tool nesting in the equipment, calibrating the equipment and producing parts.

- Control Samples Quality: to verify that the product has the specifications foreseen and required by the customer.

- Adjust Tool: requires modification of components that generate unconformities in metal parts produced. This modification may lead to changes in components design and the need to repair / rework components or fabricate new components.

- Produce Initial Samples: to produce the initial samples agreed with the customer. 


\section{2) Develop Project Management Life Cycle}

Project Management starts with the formalization of the beginning of the project (Initiation), followed by Initial Planning. The next phase consists of the Project Follow-up, which accompanies the entire Product Development. Lastly, comes the phase of the Project Closure, which formalizes the completion of the project. Table IV shows the processes and outputs of each phase.

\section{- Initiation}

Initiation is the phase where the project is described in detail so its purpose and main objectives are understood. At this phase, the integration is very importance, since the cooperation among stakeholders is determinant for the development of the project.

This phase includes the following process:

- Develop Project Charter: to document the justification and definition of the project. To do this, attention must be paid to the information in the Project Charter of the Global Project and the Minutes of the Kickoff Meting. The Tool Project Charter is a document that contains the name, description, customer and project manager; the objectives in terms of time, scope and cost; requirements; the main deliverables / milestones; and observations.

\section{- Initial Planning}

This phase aims to better define the objectives of the project and to detail the steps to achieve them. Well-developed planning is a key factor in project success [49].

This phase has only one process:

- Develop Initial Project Plan: to gather all the information necessary to carry out the project. The Initial Project Plan is a guide for the development of the plans of each knowledge area, focusing essentially on scope, time and cost planning. This plan should highlight the work to be done, the deadlines and the resources needed. So, this should contain the project identification, constraints, milestones, Work Breakdown Structure (WBS), and timeline.

Throughout the project, it is necessary to increase the detail of certain tasks, to obtain an Updated Plan of the project (Rolling Wave Planning).

\section{- Project Follow-up}

Project Follow-up is the phase that accompanies all Product Development. It is at this phase that all follow-up, replanning,

Table IV. Project Management Life Cycle

\begin{tabular}{|l|l|l|}
\hline \multicolumn{1}{|c|}{ Phase } & \multicolumn{1}{c|}{ Processes } & \multicolumn{1}{c|}{ Outputs } \\
\hline \multirow{2}{*}{ Initiation } & Develop Project Charter & Project Charter \\
\hline Initial Planning & Develop Initial Project Plan & Initial Project Plan \\
\hline \multirow{3}{*}{$\begin{array}{l}\text { Project } \\
\text { Follow-up }\end{array}$} & Develop Progress Reports & Progress Reports \\
\cline { 2 - 3 } & Update Project Plan & $\begin{array}{l}\text { Updated Project } \\
\text { Plan }\end{array}$ \\
\cline { 2 - 3 } & Fill Open Point List & Open Point List \\
\hline Project Closure & Record Lessons Learned & Lessons Learned \\
\hline
\end{tabular}

monitoring, and control measures are carried out, so that potential problems can be identified, response plans implemented and project progress communicated.

This phase includes the following processes:

- Develop Progress Reports: allows the exposure of the main problems that the sponsor should be aware of. In addition, it gives information to the stakeholders of the areas that need action and the problems they must solve. Progress Reports are documents that should evidence work progress and deviations from the planned timeline.

- Update Initial Project Plan: it is a necessity that arises as the project progresses, since the level of detail is higher and the project can suffer changes. The Updated Plan allows us to have an updated and correct image of the project realization forecast. This plan shall contain all changes to the Initial Project plan, including updates arising from risk responses.

- Fill Open Point List (OPL): allows the creation and management of a list of open points that need to be completed for the successful execution of the project. OPL are documents that consist of a list of activities that need to be accomplished by the end of the project. The list should identify the activity, the person responsible, the deadline and the status.

\section{- Project Closure}

Project Closure formalizes the finalizing of the project, having as main output the Lessons Learned.

This phase has only one process:

- Record Lessons Learned: it is a source of continuous improvement of project management, as it highlights the problems that have arisen during the project and should be avoided in future projects. Therefore, Lessons Learned is a document that should identify the main problems encountered in the project, leave recommendations to adopt in future projects and make an analysis of the project's performance.

3) Integrate the Project Management Life Cycle and Product Life Cycle

Interconnections between project management and product development processes occur in several moments (Fig. 1). After the budget approval, the Kick-off Meeting takes place. Developing the Project Charter and the Initial Project Plan are the following steps. The documents produced should reflect the workload of the resources involved in the NPD process, so it is very important the communication with all the stakeholders, especially the team. After these steps, there are conditions to execute the project, starting with the Design, followed by the Manufacture and finally the Tests. The Project Follow-up accompanies the entire development of the product. The processes of this phase are cyclical, since it is necessary to be in constant update of the information. Once again, the communication assumes relevance, in which the NPD processes must be executed, monitored and controlled, and replanned. Finally, the Project Closure records the lessons learned from the project. 
In addition to the relationship between the processes, the relationship between the outputs was elaborated, both for the integration of the project management life cycle and product life cycle, and for the integration of the subproject with the global project. However, due to lack of space, it was not possible to incorporate a detailed analysis of these issues in this paper.

\section{B. Integration of Subproject with the Global Project}

The relationship between the subproject and the global project must be ensured so that coordination of both is possible. It is then necessary to integrate the processes of the subproject with those of the global project (Fig. 2). Then, it is necessary to know the processes of the global project. Although the outputs of each phase of the global project are well defined, the processes associated with each phase did not have a clear identification, so Table $\mathrm{V}$ represents the global project life cycle.

The subproject occurs during the last 5 phases of the global project. Initiation and Initial Planning processes take place in the Preparation of Initial Samples; Design processes occur in the Studies of Initial Samples; Manufacture processes occur in the Development of Definitive Means; Tests processes occur in the Execution of Initial Samples; Project Follow-up processes relate to the Monitor and Control process; and Project Closure processes occurs in the Monitoring.

TABLE V. Global Project Life Cycle

\begin{tabular}{|c|c|c|}
\hline Phase & Processes & Outputs \\
\hline \multirow{3}{*}{ Preparation of Prototypes } & Open Project & $\begin{array}{l}\text { Project Charter } \\
\text { Minutes of Kick-off Meeting }\end{array}$ \\
\hline & Open Costumer in Management Systems & $\begin{array}{l}\text { Primavera and Job Boss codes open } \\
\text { Costumer open in Primavera } \\
\text { Routing inserted in Job Boss } \\
\text { BOM inserted in Job Boss }\end{array}$ \\
\hline & Develop Baseline Plan & Baseline Plan \\
\hline \multirow{6}{*}{ Execution of Prototypes } & Order material and raw material & Purchase Orders \\
\hline & Update Information in Management Systems & BOM and Routing updated in Job Boss \\
\hline & Monitor and Control & $\begin{array}{l}\text { Minutes of Plan Review Meetings } \\
\text { Updated Plan }\end{array}$ \\
\hline & Develop Soft Tools & Soft Tools \\
\hline & Develop Prototypes & $\begin{array}{l}\text { Machined Prototypes } \\
\text { Validated Prototypes }\end{array}$ \\
\hline & Deliver Prototypes & Sent Prototypes \\
\hline \multirow{3}{*}{ Preparation of Initial Samples } & Open Project & $\begin{array}{l}\text { Project Charter } \\
\text { Minutes of Kick-off Meeting }\end{array}$ \\
\hline & Open Costumer in Management Systems & $\begin{array}{l}\text { Primavera and Job Boss codes open } \\
\text { Costumer open in Primavera } \\
\text { Routing inserted in Job Boss } \\
\text { BOM inserted in Job Boss }\end{array}$ \\
\hline & Develop Baseline Plan & Baseline Plan \\
\hline \multirow{3}{*}{ Studies of Initial Samples } & Designing Tool & Tool Design \\
\hline & Order material and raw material & Purchase Orders \\
\hline & Monitor and Control & $\begin{array}{l}\text { Minutes of Plan Review Meetings } \\
\text { Updated Plan }\end{array}$ \\
\hline \multirow{4}{*}{ Development of Definitive Means } & Develop Pre-Launch Control Plan & Pre-Launch Control Plan \\
\hline & Develop Means of Control & Means of Control \\
\hline & Update Information in Management Systems & BOM and Routing updated in Job Boss \\
\hline & Manufacturing Tool & Tool Produced \\
\hline \multirow[t]{5}{*}{ Execution of Initial Samples } & Develop Initial Samples & $\begin{array}{l}\text { Machine Set Up } \\
\text { Operation Performed } \\
\text { Heat Treatment Performed } \\
\text { Surface Treatment Performed } \\
\text { Initial Samples Produced }\end{array}$ \\
\hline & Control the Quality of the Initial Samples & Dimensional Control Report \\
\hline & Deliver Initial Samples & Sent Initial Samples \\
\hline & Develop Production Control Plan & Production Control Plan \\
\hline & Submit Documentation & Documentation Submitted \\
\hline \multirow{6}{*}{ Monitoring } & Develop Inspection and Testing Plan & Inspection and Testing Plan \\
\hline & Obtain Costumer Approval & $\begin{array}{l}\text { Costumer Approval } \\
\text { Monitoring Completed }\end{array}$ \\
\hline & Review Information in Management Systems & $\begin{array}{l}\text { Routing revised in Job Boss } \\
\text { BOM revised in Job Boss }\end{array}$ \\
\hline & Adjust Tool & Adjusted Tool \\
\hline & Perform Closing & Minutes of Closing Meeting \\
\hline & Archive Documentation & Archived Documentation \\
\hline
\end{tabular}




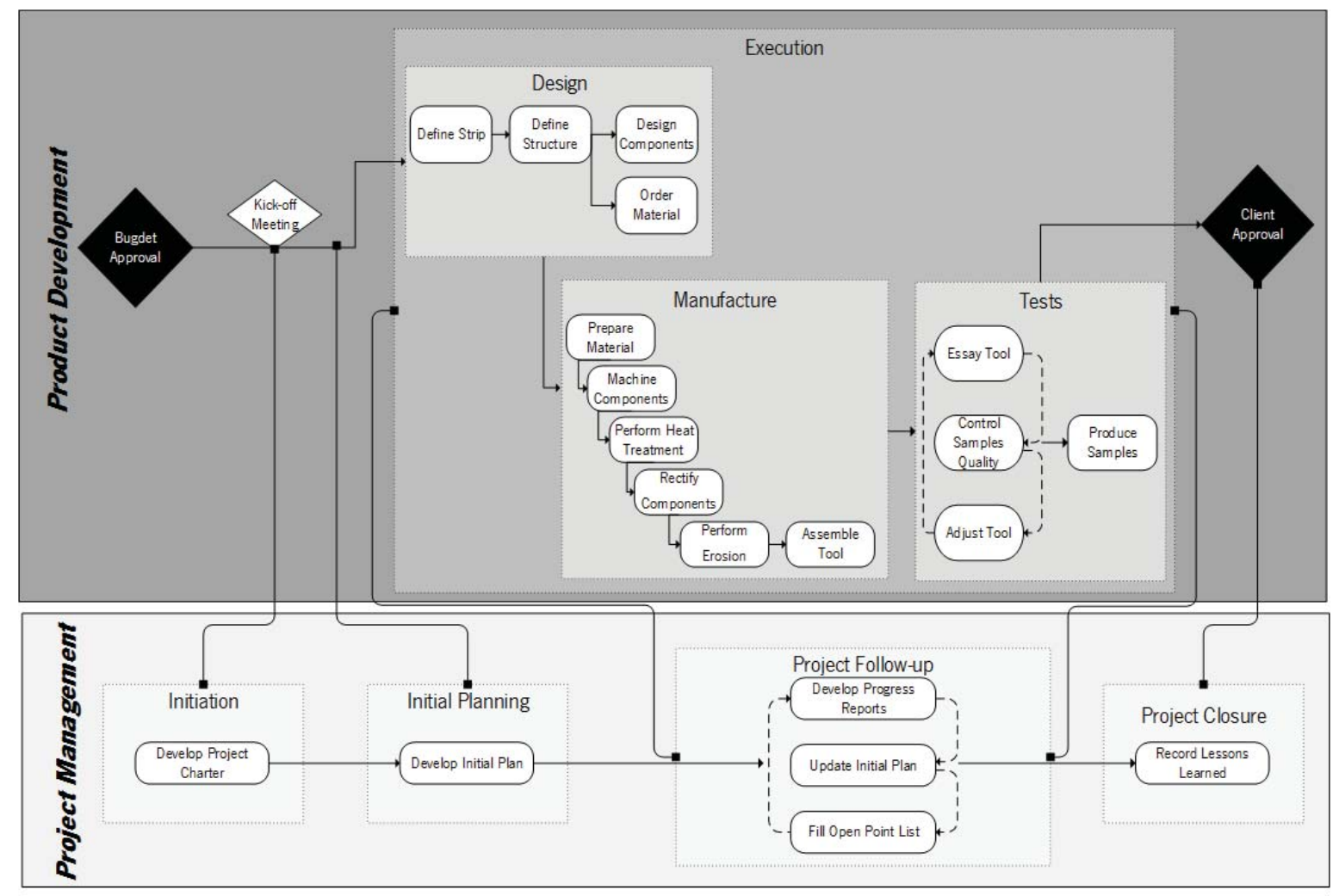

Fig. 1. Integration of Project Management with NPD Process.

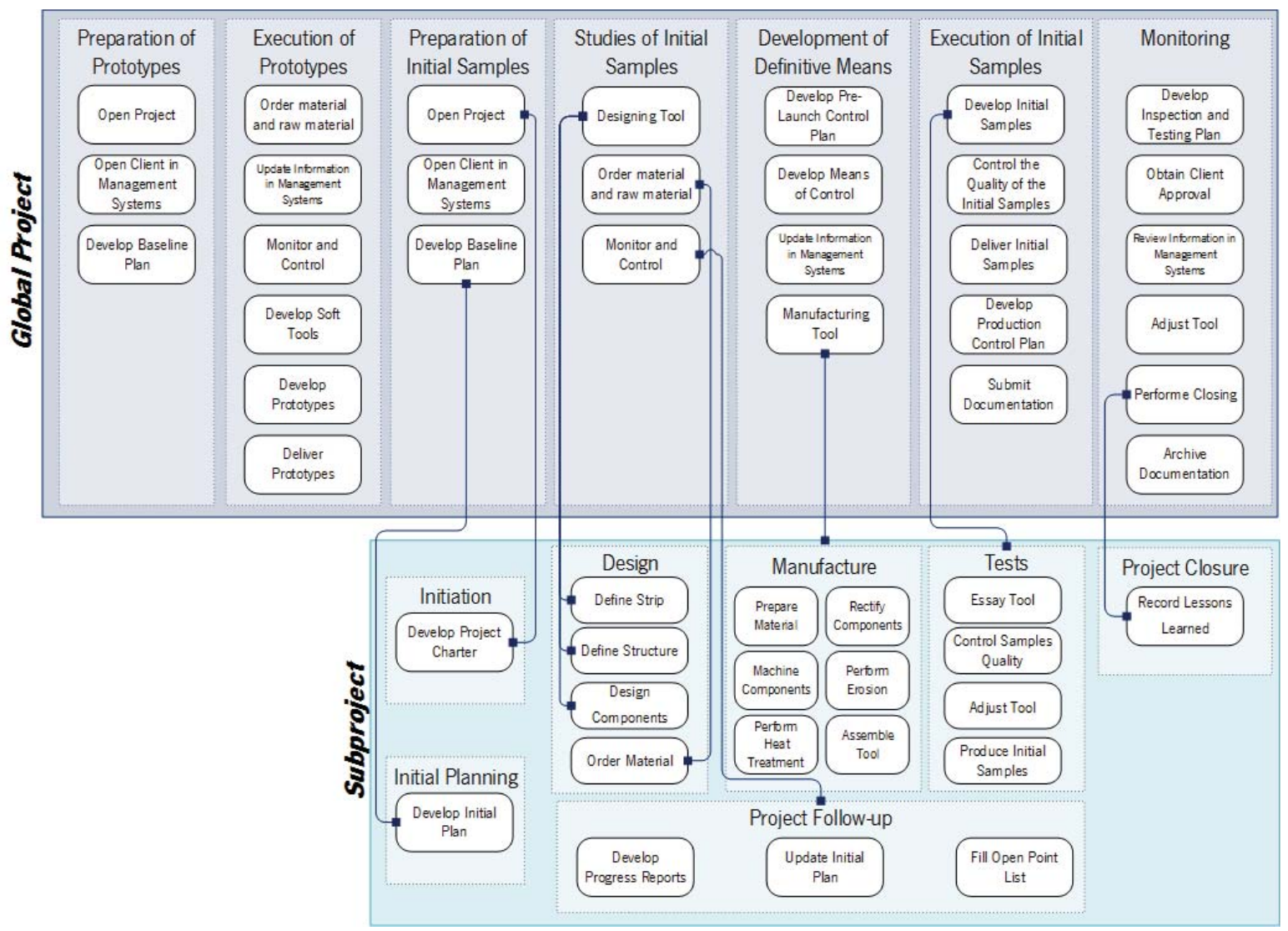

Fig. 2. Integration of Subproject with the Global Project. 


\section{CONCLUSIONS}

The main contribution of this paper is to practice, by demonstrating, using a case study, how to integrate the project management process with the NPD process. This research may be useful for similar companies, considering that project management is context dependent and must be adapted to each project.

The integrated project management process proposed is composed by six main project management practices: project charter, initial project plan, progress reports, updated plan, open point list and lessons learned. Through the project management process proposed, it is possible to understand the integration of the subproject management with the global project management and the interconnection between the project management process and the product development process

The case study methodology applied to just one case has the limitation of not allowing for generalizations, but the goal of this research was not to generalize findings but rather to make a contribution on the way a company can integrate project management with the NPD process, serving as a benchmark to other companies of the same field with similar problems.

During the research, some aspects had to be considered:

- $\quad$ The use of project management practices was new to the project team;

- The project team found it difficult to understand the value of project management for project success;

- The project team lacked knowledge about project management;

- It was difficult to influence the project team to devote more time to project management activities.

These aspects are common to most companies that deal with projects. Project management maturity is low in most sectors of activity [50]. Therefore, it is necessary to ensure that the project team understands project management practices and is motivated to use them. Furthermore, one of the main concerns during the development of this integrated project management process was its ease of use, since this is a decisive factor for the incorporation of project management practices in the company [51].

The next step of the research will be the implementation of the integrated process project management in the company. This will require the collaboration of the project team. Subsequently, the analysis of the changes that the practices adoption provoked in the projects will be carried out, in order to implement improvements.

For future work, it would be interesting to implement this integrated process in other companies of the same industry with similar projects, to validate the applicability of the approach widely. As abovementioned, this work can be used as a benchmark study for other companies of the field. External benchmarking occurs when a company compares itself with other organizations [52], stimulating continuous improvement and allowing learning from the best practices of other organizations [53]. Although benchmarking brings advantages, the fact that the projects have a unique nature makes the comparison more difficult [52]. So, it is very important finding the 'right' companies to benchmark, to allow a meaningful comparative analysis.

\section{REFERENCES}

[1] S. S. Willaert, R. De Graaf, and S. Minderhoud, "Collaborative engineering: A case study of Concurrent Engineering in a wider context," Journal of Engineering and Technology Management, vol 15, pp. 87-109, 1998

[2] W. Bai, Y. Feng, Y. Yue, and L. Feng, "Organizational Structure, Cross-functional Integration and Performance of New Product Development Team," Procedia Engineering, vol. 174, pp. 621-629, 2017.

[3] D. Pons, "Project management for new product development," Project Management Journal, vol. 39, pp. 82-97, 2008.

[4] S. Rawat and B. R. Divekar, "Assessing integration between project management with npd process in heavy industrial components industry and developing a framework to align them," Procedia Economics and Finance, vol. 11, pp. 726-736, 2014.

[5] D. Dougherty, "Interpretive barriers to successful product innovation in large firms," Organization science, vol. 3, pp. 179-202, 1992.

[6] P. S. Adler, "Interdepartmental interdependence and coordination: The case of the design/manufacturing interface," Organization science, vol. 6, pp. 147-167, 1995

[7] S. Pugh, Total design: integrated methods for successful product engineering: Addison-Wesley, 1991.

[8] L. Berchicci and W. Bodewes, "Bridging environmental issues with new product development," Business Strategy and the Environment, vol. 14, pp. 272-285, 2005.

[9] G. Gemser and M. A. Leenders, "Managing cross-functiona cooperation for new product development success," Long Range Planning, vol. 44, pp. 26-41, 2011.

[10] M. A. Leenders and B. Wierenga, "The effect of the marketing-R\&D interface on new product performance: The critical role of resources and scope," International Journal of Research in Marketing, vol. 25, pp. 56-68, 2008.

[11] C. Nakata and S. Im, "Spurring cross-functional integration for higher new product performance: A group effectiveness perspective," Journal of Product Innovation Management, vol. 27, pp. 554-571, 2010.

[12] L. C. Troy, T. Hirunyawipada, and A. K. Paswan, "Cross-functiona integration and new product success: an empirical investigation of the findings," Journal of Marketing, vol. 72, pp. 132-146, 2008.

[13] W. Belassi, A. Z. Kondra, and O. I. Tukel, "New product development projects: The effects of organizational culture," Project Management Journal, vol. 38, pp. 12-24, 2007.

[14] R. Leus and W. Herroelen, "Stability and resource allocation in project planning," IIE transactions, vol. 36, pp. 667-682, 2004.

[15] W. Herroelen and R. Leus, "Project scheduling under uncertainty: Survey and research potentials," European journal of operational research, vol. 165, pp. 289-306, 2005.

[16] M. V. Tatikonda and S. R. Rosenthal, "Successful execution of product development projects: Balancing firmness and flexibility in the innovation process," Journal of Operations Management, vol. 18, pp. 401-425, 2000 .

[17] M. W. Lewis, M. A. Welsh, G. E. Dehler, and S. G. Green, "Product development tensions: Exploring contrasting styles of project management," Academy of Management Journal, vol. 45, pp. 546-564, 2002.

[18] E. Commission, "The new SME definition: User guide and model declaration," ed. Luxembourg: Publications Office of the European Union, 2015

[19] Y.-H. Kwak, "A brief history of project management," ed: Greenwood Publishing Group, 2005.

[20] PMI, "A Guide to the Project Management Body of Knowledge," $5^{\text {a }}$ ed. Pennsylvania: Project Management Institute, Inc., 2013.

[21] ISO, "21500: 2012: Guidance on Project Management," International Organization for Standardization, 2012

[22] IPMA, IPMA Individual Competence Baseline Version 4.0. Nijkerk, Netherlands: International Project Management Association, 2015.

[23] PMAJ, Guidebook of Project \& Program Management for Enterprise Innovation. Japan: Project Management Association of Japan, 2005. 
[24] A. Lester, Project management, planning and control: managing engineering, construction and manufacturing projects to PMI, APM and BSI standards: Butterworth-Heinemann, 2006.

[25] PMI. (2016, Pulse of the Profession 2016. The High Cost of Low Performance: How will you improve business results? Available: https://www.pmi.org/learning/thought-leadership/pulse/pulse-of-theprofession-2016

[26] A. J. Shenhar, D. Dvir, O. Levy, and A. C. Maltz, "Project success: a multidimensional strategic concept," Long range planning, vol. 34, pp. 699-725, 2001.

[27] J. R. Meredith and S. J. Mantel, Project management: a managerial approach, $8^{\text {a }}$ ed.: John Wiley \& Sons, 2012.

[28] G. Y. Abbasi and H. Al-Mharmah, "Project management practice by the public sector in a developing country," International Journal of Project Management, vol. 18, pp. 105-109, 2000.

[29] J. K. Pinto and O. P. Kharbanda, "How to fail in project management (without really trying)," Business Horizons, vol. 39, pp. 45-53, 1996.

[30] É. N. C. Besteiro, J. de Souza Pinto, and O. Novaski, "Success Factors in Project Management," Business Management Dynamics, vol. 4, pp. 19-34, 2015.

[31] R. Pinto and C. Dominguez, "Characterization of the practice of project management in 30 Portuguese metalworking companies," Procedia Technology, vol. 5, pp. 83-92, 2012.

[32] T. R. Browning and R. V. Ramasesh, "A Survey of Activity NetworkBased Process Models for Managing Product Development Projects," Production and operations management, vol. 16, pp. 217-240, 2007.

[33] D. Gerwin and N. J. Barrowman, "An evaluation of research on integrated product development," Management Science, vol. 48, pp. 938-953, 2002.

[34] T. Hirotaka Business Review, vol. 64, pp. 137-146, 1986.

[35] R. Balachandra, "An expert system for new product development projects," Industrial Management \& Data Systems, vol. 100, pp. 317 324, 2000.

[36] J. Jayaram and M. K. Malhotra, "The differential and contingent impact of concurrency on new product development project performance: a holistic examination," Decision Sciences, vol. 41, pp. 147-196, 2010

[37] M. P. Knudsen, "The relative importance of interfirm relationships and knowledge transfer for new product development success," Journal of Product Innovation Management, vol. 24, pp. 117-138, 2007.

[38] X. A. Koufteros, G. E. Rawskiand N. Ikujiro, "The new new product development game," Harvard, and R. Rupak, "Organizational integration for product development: the effects on glitches, on-time execution of engineering change orders, and market success," Decision Sciences, vol. 41, pp. 49-80, 2010.

[39] E. Naveh*, "The effect of integrated product development on efficiency and innovation," International Journal of Production Research, vol. 43, pp. 2789-2808, 2005.
[40] R. Rauniar, W. Doll, G. Rawski, and P. Hong, "The role of heavyweight product manager in new product development," International Journal of Operations \& Production Management, vol. 28, pp. 130-154, 2008

[41] M. Tracey, "A holistic approach to new product development: new insights," Journal of Supply Chain Management, vol. 40, pp. 37-55, 2004.

[42] C. A. Un, A. Cuervo-Cazurra, and K. Asakawa, "R\&D collaborations and product innovation," Journal of Product Innovation Management, vol. 27 , pp. $673-689,2010$

[43] J. M. Nicholas and H. Steyn, Project management for business, engineering, and technology: Principles and practice, 4 ed.: Routledge, New York, 2012.

[44] T. Laine, T. Korhonen, and M. Martinsuo, "Managing program impacts in new product development: An exploratory case study on overcoming uncertainties," International Journal of Project Management, vol. 34, pp. 717-733, 5// 2016.

[45] R. Abrantes and J. Figueiredo, "Feature based process framework to manage scope in dynamic NPD portfolios," International Journal of Project Management, vol. 32, pp. 874-884, 2014.

[46] M. Saunders, P. Lewis, and A. Thornhill, Reseach Methods for Business Students, $5^{\text {a }}$ ed. England: Pearson Education Limited, 2009.

[47] P. W. Morris, L. Crawford, D. Hodgson, M. M. Shepherd, and J. Thomas, "Exploring the role of formal bodies of knowledge in defining a profession-The case of project management," International Journal of Project Management, vol. 24, pp. 710-721, 2006.

[48] O. McHugh and M. Hogan, "Investigating the rationale for adopting an internationally-recognised project management methodology in Ireland: The view of the project manager," International Journal of Project Management, vol. 29, pp. 637-646, 2011.

[49] I. Attarzadeh and S. H. Ow, "Project management practices: the criteria for success or failure," Communications of the IBIMA, vol. 1, pp. 234 $241,2008$.

[50] D. Silva, A. Tereso, G. Fernandes, I. Loureiro, and J. Â. Pinto, "OPM3 $®$ Portugal Project-Information Systems and Technologies Organizations-Outcome Analysis," in New Contributions in Information Systems and Technologies, ed: Springer, 2015, pp. 469479.

[51] G. Fernandes, S. Ward, and M. Araújo, "Developing a framework for embedding useful project management improvement initiatives in organizations," Project Management Journal, vol. 45, pp. 81-108, 2014.

[52] E. Barber, "Benchmarking the management of projects: a review of current thinking," International Journal of Project Management, vol. 22, pp. 301-307, 2004.

[53] V. T. Luu, S.-Y. Kim, and T.-A. Huynh, "Improving project management performance of large contractors using benchmarking approach," International Journal of Project Management, vol. 26, pp. 758-769, 2008. 